Portland State University

PDXScholar

1982

\title{
Feeding and food selection in the Japanese oyster Crassostrea gigas
}

Rickey D. Moore

Portland State University

Follow this and additional works at: https://pdxscholar.library.pdx.edu/open_access_etds

Part of the Biology Commons, Food Microbiology Commons, and the Marine Biology Commons Let us know how access to this document benefits you.

Recommended Citation

Moore, Rickey D., "Feeding and food selection in the Japanese oyster Crassostrea gigas" (1982). Dissertations and Theses. Paper 3175.

https://doi.org/10.15760/etd.3166

This Thesis is brought to you for free and open access. It has been accepted for inclusion in Dissertations and Theses by an authorized administrator of PDXScholar. Please contact us if we can make this document more accessible: pdxscholar@pdx.edu. 
AN ABSTRACT OF THE THESIS OF Rickey D. Moore for the Master of Science in Biology presented May 26, 1982.

Title: Feeding and Food Selection in the Japanese Oyster Crassostrea gigas.

APPROVED BY MEMBERS OF THE THESIS COMMITTEE:
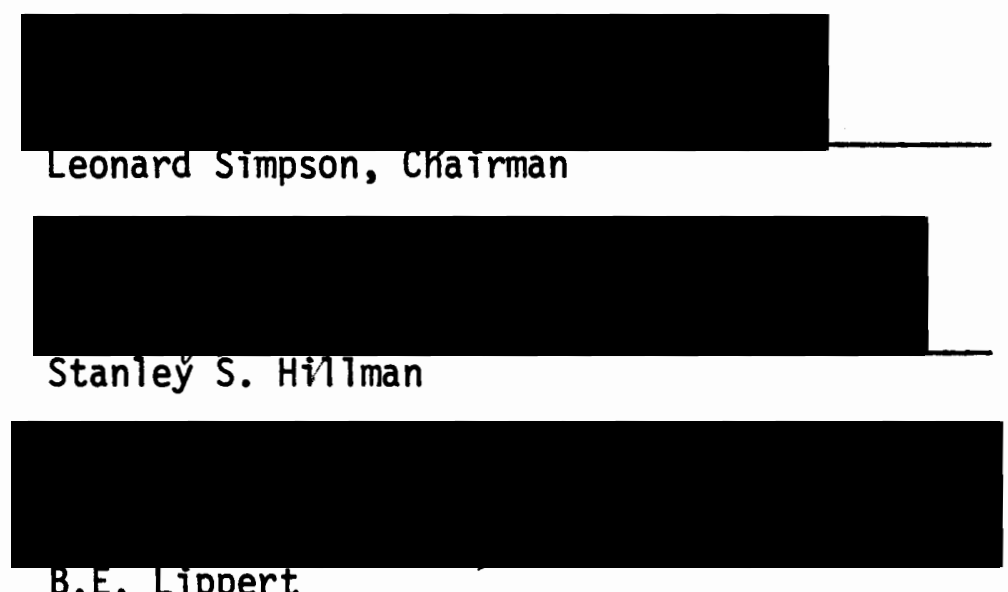

B.E. Lippert

The Japanese oyster Crassostrea gigas is commercially grown in bays and estuaries of the Pacific Northwest. The oyster's complex, ciliated, plicate gill is responsible for removing particles from surrounding waters for ingestion. In order to determine how this is accomplished, structural interrelationships of gill components were investigated using scanning electron microscopy and light microscopy. Particle movement was observed directly on both isolated gill sections and intact gills. Feeding data were obtained by comparing initial to final concen- 
tration and size of algal particles in a Coulter counter.

Each gill lamella is formed from two tissue sheets attached at regular intervals by tissue junctions forming water tubes between the lamella. The lamellae are plicate or pleated, each plica consisting of $13-17$ ordinary filaments. Principal filaments are located between plicae. Both ordinary and principal filaments contain ciliary tracts that create currents which move particles dorsally or ventrally. Particles that are moved ventrally adhere to a mucus strand in the ventral food groove and are rejected at the palp. Particles that move dorsally are not incorporated into mucus.

Structural data, direct observation and feeding experiments lead to the conclusion that larger particles are more likely to be intercepted by the gill than smaller particles. Mucus is not directly involved in food capture, but is produced in response to physical stimulation and is rejectory. 
FEEDING AND FOOD SELECTION IN THE

JAPANESE OYSTER CRASSOSTREA GIGAS

by

RICKEY D. MOORE

A thesis submitted in partial fulfillment of the requirements for the degree of

\author{
MASTER OF SCIENCE \\ in \\ BIOLOGY
}

PORTLAND STATE UNIVERSITY 
TO THE OFFICE OF GRADUATE STUDIES AND RESEARCH:

The members of the Committee approve the thesis of Rickey D. Moore presented May 26, 1982.

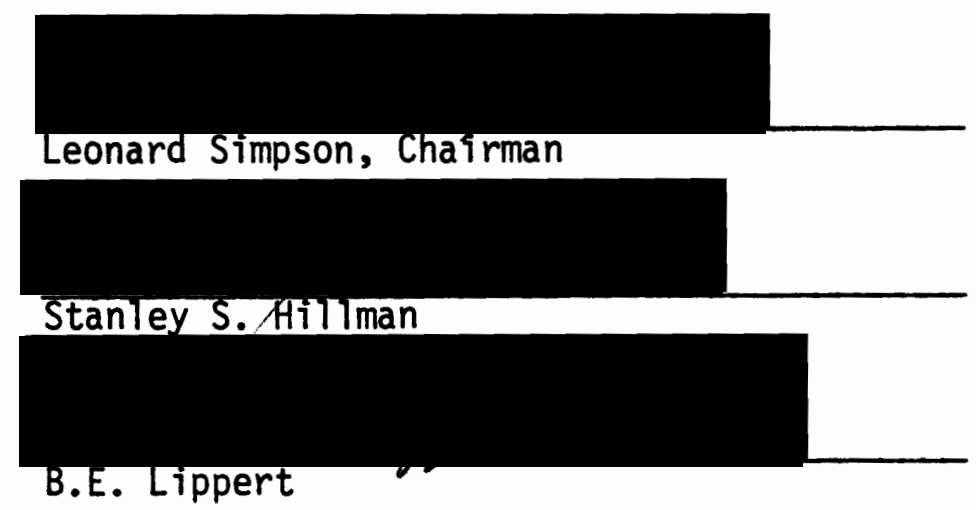

APPROVED:

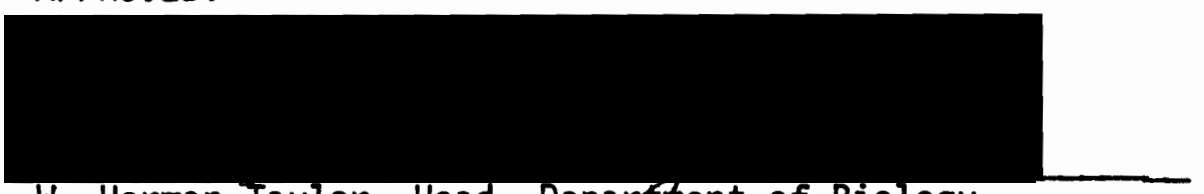

W. Herman Taylor, Head, Depapthent of Biology

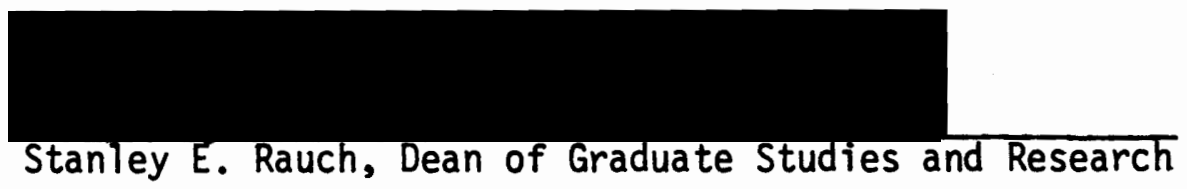




\section{ACKNOWLEDGMENTS}

I would like to thank Dr. Leonard Simpson, graduate committee chairman, for his support and assistance in this project. Thanks also to Dr. Stan Hillman and Dr. B.E. Lippert for serving on my committee. I would also like to acknowledge Dr. W.H. Fahrenbach of the Oregon Regional Primate Center for his technical assistance with scanning electron microscopy, Dr. Richard Petersen for guidance in Coulter counter techniques and Sue E. Orlaske for preparing the line diagram in Figure 9. 
TABLE OF CONTENTS

PAGE

ACKNOWLEDGMENTS. . . . . . . . .

LIST OF FIGURES . . . . . . . . . . V v

LITERATURE REVIEW ............ . . 1

INTRODUCTION. ................... 8

METHODS AND MATERIALS .......... 10

RESULTS ................... 12

DISCUSSION. . . . . . . . . . . 27

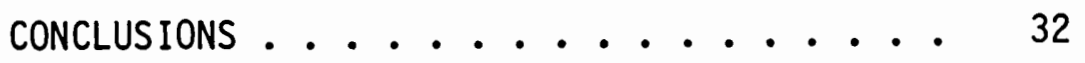

REFERENCES. ............ 33 


\section{LIST OF FIGURES}

FIGURE

PAGE

1. Representative gill morphologies in bivalve molluscs...................... 2

2. Simple diagramatic view of C. gigas ...... 13

3. Scanning Electron Micrograph of frontal section of gill lamella of C. gigas $(100 \mathrm{X})$. . . . . . 14

4. Scanning Electron Micrograph of frontal section of gill lamella of C. gigas $(200 \mathrm{X})$. . . . . . 15

5. Scanning Electron Micrograph of cross section of gill lamella of C. gigas $(200 \mathrm{X})$. . . . . 16

6. Scanning Electron Micrograph of sagital section of gill lamella of C. gigas $(200 \mathrm{X})$. . . . . 17

7. Scanning Electron Micrograph of frontal section of gill lamella of C. gigas $(1000 \mathrm{x})$....... 18

8. Scanning Electron Micrograph of frontal section of gill lamella of C. gigas $(1000 \mathrm{x})$...... 19

9. Line drawing of plicate gill lamella frontal section indicating water flow ......... 21

10. Suspension concentration at time 0 and time 60. . 24

11. Mean particle diameter at time 0 and time 60. . 26 


\section{LITERATURE REVIEW}

Crassostrea gigas is the largest member of the family Ostreidae, ranging up to $30 \mathrm{~cm}$ in shell length (Smith and Carlton 1977). The assymetric, fluted valves are hinged anteriorly with opening and closing controlled by a single adductor muscle. The left valve is deeply cupped while the right valve is relatively flat. The foot is greatly reduced and the animal is sessile as an adult. It may be found attached to rocks or more commonly lying in the mud of protected bays and estuaries.

The observation that bivalves effectively use their gills to remove food particles from the water is scarcely controversial, but precisely how this is done is often debated at great length. Among the bivalves are a variety of gill morphologies, each specialized to perform effectively in its own environment. So characteristic are the bivalve gills that they are used in taxonomic classification to separate the bivalves into three subclasses: Protobranchia, Lamellibranchia and Septibranchia (Barnes 1976).

The most primitive gill type, the protobranch (Fig. la) was present in many extinct bivalves and is found in some extant forms such as Nucula sp., a burrowing clam. It is reported that the primary function of the protobranch gill is ventilatory gas exchange (Jorgensen 1966), although in some more advanced 


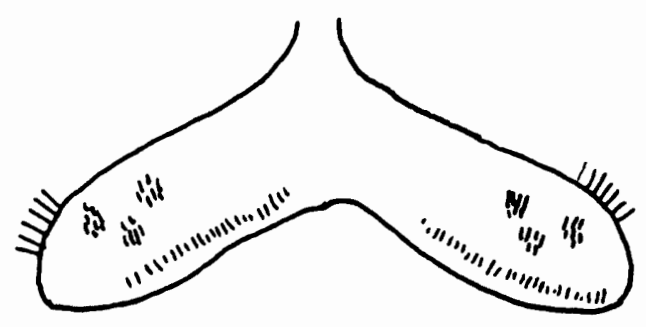

a

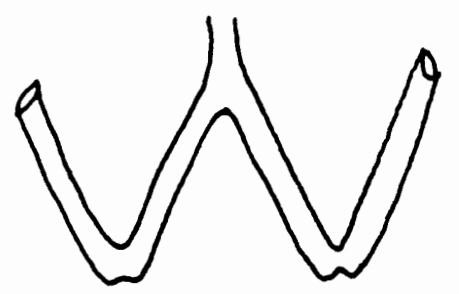

b

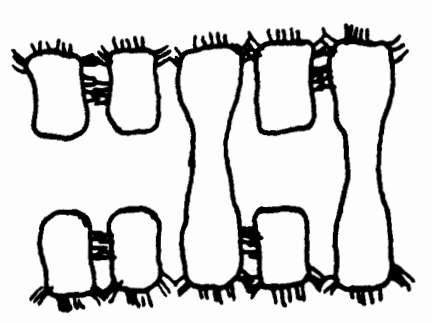

C

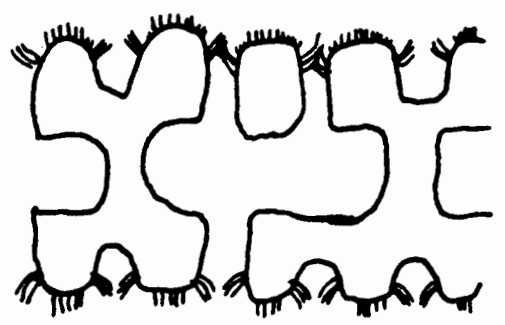

d

Figure 1. Representative gill morphologies in bivalve molluscs. (a) protobranch, (b) lamellibranch, (c) frontal view of filibranch,, (d) frontal view of eulamellibranch, (after Barnes 1976). 
protobranchs the gill is also involved in feeding. The Lamellibranchia have two major gill types, the filibranch and the eulamellibranch. The filibranch gill (Fig. Ic) is exemplified by Mytizus a bivalve commonly found attached to rocks on the open coast. Unlike the protobranchs, the filibranch gill is a complexly folded, highly ciliated organ that is adapted for the efficient collection of food particles from the surrounding waters as well as ventilatory gas exchange. The eulamellibranchs have the most highly adapted gill. In this type of gill, the lamellae are formed from tissues that are connected by tissue junctions. These gills are often plicate, adding to their already complex structure. Crassostrea is a member of this group. The septibranchs, a highly specialized form of bivalve, have secondarily lost their gills. Due to the structural diversity among the bivalve's gills, it is of little value to compare any but the most general observations among the genera.

Ciliary activity, for example, is an essential component of filter feeding. The lateral cilia create currents that move water through the gill, the laterofrontal cilia filter particles from the water and transfer them to the frontal cilia which in turn transport them to the food grooves (Winter 1978). Direction of the beating frontal cilia varies interspecifically, some species moving particles ventrally to ventral food grooves and some species moving particles dorsally to dorsal food arooves. In some species 
both dorsally and ventrally beating cilia are present on the same filament. In this case, the dorsally beating cilia are normally in motion and the ventrally beating cilia are stimulated by large or heavy particles (Atkins 1936). In bivalves with plicate gills, the ordinary filaments may possess both ventrally and dorsally beating cilia while the principal filaments possess only dorsally beating cilia.

The idea that filter feeders strain particles through a sieve or mesh strainer is widespread in the field. This theory seems to be supported by the observation that the laterofrontal cirri of Mytilus edulis forms a meshed network of the proper dimension across the ostia to remove particles by straining them out of the water and passing them on to the frontal cilia for transport (Dral 1967, Moore 1971, Owen 1974). Particle retention studies indicate that bivalves such as Mytizus are able to efficiently remove particles as small as 1 - $2 \mu \mathrm{m}$ in diameter (Jorgensen and Goldberg 1953). The distance between the laterofrontal cilia was measured at $3 \mu \mathrm{m}$ when the cilia from adjacent filaments overlap to as much as $6 \mu \mathrm{m}$ when the cilia don't overlap (Jorgensen 1966). Tammes and Dral (1955) had suggested that the particles adhere to mucus covering these cilia. Moore (1971) observed no mucus coating on the laterofrontal cirri and suggested that it would make the transfer of particles from the cirri to the frontal cilia quite cumbersome. Moore (1971), Owen (1974) and Jørgensen (1975) studied the laterofrontal cilia in greater detail and found that each was 
composed of a branching network of cilia. The overlapping of these cilia form a meshed network of $0.6-2.4 \mu \mathrm{m}$. This may explain the capacity of Mytizus to filter extremely fine particles.

Buley (1936) compared stomach contents of Mytizus to plankton samples taken from the surrounding waters. He found that $97 \%$ of the gut content was of a diatom that comprised only $3 \%$ of the plankton samples. Unforunately, it was later discovered that the plankton net used for sampling was not of the proper mesh size to accurately sample that size of diatom, and the seven month study was invalidated. Loosanoff (1949) showed that Crassostrea virginica rejected yeast cells in favor of similarly sized algal cells. He also reported some selectivity between purple sulfur bacteria and algal cells, observing that the smaller $(2-3 \mu \mathrm{m})$ bacteria were rejected as pseudofeces while the larger algal cells were ingested. His observations were based on the fact that the pseudofeces produced were bright purple and the true feces were greenish brown. After a short period of time the oysters stopped producing purple psuedofeces and began ingesting the bacteria with the alga. Loosanoff interprets this observation as evidence for selectivity based on chemical composition of cells. Bernard (1974) disagrees saying that the bacteria were not rejected because of their cell composition, but because of the $\mathrm{H}_{2} \mathrm{~S}$ produced during their growth phase. Bernard also showed that the bacteria were rapidly lysed in the gut of the oyster and the 
purple color that Loosanoff expected to see in the feces was not necessarily a good indicator of ingestion.

The use of mucus in food capture is routinely observed in suspension feeding (Nelson 1960, Bernard 1974, MacGinitie 1941). MacGinitie (1941) cut windows in the shell of bivalves to observe the movement of particles on the gill surface in a relatively undisturbed state. It appeared to MacGinitie that all the particles introduced to the gill surface were moving along the gill at the same rate toward the ventral margin and being incorporated into a mucus strand in the ventral food groove. He postulated that the gill was covered by a sheet of mucus that the particles adhered to. The entire mucus sheet was then rolled into a strand and carried to the mouth for ingestion. This process has been questioned by Jorgensen (1966) who argues that it is highly unlikely that such an intricate organ as the gill would be totally covered by a mucus sheet.

Bernard (1974) removed the anterior portion of the shell of C. gigas in order to observe particle movement in relation to mucus flow. He reported observing a $5 \mu \mathrm{m}$ thick serous fluid which covered the gill surface. This fluid was not subject to ciliary action. Two distinct types of mucus that are involved in filtering activity were also observed. A $12 \mu \mathrm{m}$ thick by $20 \mu \mathrm{m}$ wide mucus band was observed overlaying the frontal cilia. Particles adhering to this mucus were carried to the ventral food grooves. Stimulation of the gill induced production of a 250 $400 \mu \mathrm{m}$ thick sheet of mucus. It was apparently too thick to be 
incorporated into the ventral food groove and fell onto the mantle for rejection as pseudofeces. Bernard suggests that this may be the mucus sheet that MacGinitie observed during his investigations. Jorgensen (1981) suggests that the laterofrontal cirri may not be used for filtering as such, but function to aid in creating water currents, and that the complex interaction of these ciliary currents create velocity gradients. It is this interaction among water currents and velocity gradients that determine which particles will be swept through the gills, which will be rejected as pseudofeces, and which will be selected for ingestion. This may have a wider base of application than the laterofrontal straining theory since many bivalves as well as other suspension feeders don't have overlapping ciliary meshes. 


\section{INTRODUCTION}

The precise mechanisms by which suspension feeding bivalves efficiently remove particles from their surrounding waters has long evaded investigators in this field. It is generally accepted that the gills of most bivalves are their major food collecting organs, but there is little agreement as to the method of particle capture, degree of selectivity, or ability to discriminate among particles.

The prevailing theory of suspension feeding is one of straining water through a sieve or mesh network which removes the particles (Jørgensen 1966, Moore 1971, Jørgensen 1975, Owen and McCrae 1976, Rubenstein and Koeht 1977). This is based on the observation that the laterofrontal cirri of Mytilus edulis appear microscopically to form sieve-like structures across the ostia of a dimension that may explain small particle capture. A problem with this theory is that it doesn't explain how particles that are larger than the filter mesh pass through, nor how this relatively fine meshed filter keeps from clogging with sediment.

Mucus entrapment is the second most popular theory of feeding in these bivalves. MacGinitie (1941) and Bernard (1974) both observed sheets of mucus that totally covered the gill lamellae. MacGinitie interpreted the mucus sheet as capturing food particles for ingestion while Bernard observed it as being rejectory. In either case, an explanation of why this mucus sheet 
is not sucked down tightly against the gill lamella is necessary. Also unexplained is how water flow through the gill is maintained when it is sealed by this sheet of mucus.

Bernard (1974) suggests that some selectivity is accomplished by the effects of gravity on the particles as they enter the mantie cavity. His theory is based on the difference in flow rates between the inhalent region and the mantle cavity of Crassostrea gigas, making the mantle cavity a virtual settling chamber which separates heavy (inorganic) from light (organic) particles. If gravity were an important factor in this feeding process, one would expect to find differences between the right and left sides of gill lamellae. This has not been shown. Nor has it been shown that particles impinge on one lamellar surface more often than another.

This study was undertaken in response to the apparent porosity of the literature on suspension feeding bivalves. Particle selection data are presented in concert with observations of Crassostrea gigas in the laboratory and in the field. Scanning electron microscopic ultrastructural aspects of gill morphology are included to compliment feeding data and to aid the investigator in data interpretation. This synthesis of filtering data, structural analysis, and observation in natural habitat is necessary to fully understand the mechanisms involved in suspension feeding. 


\section{METHODS AND MATERIALS}

Oysters were collected from Willapa Bay in Southwest Washington and maintained in $30 \%$ sea water at $10^{\circ} \mathrm{C}$. Animals were anesthetized by adding epsom salts $\left(\mathrm{MgSO}_{4}\right)$ slowly to the sea water until their valves began to gap ( 5 - $15 \mathrm{~min})$. The oyster was then quickly opened and 0.5 to $1.0 \mathrm{~cm}$ squares of gill lamella were dissected out and placed immediately into Bouin's fluid for a 12 - $18 \mathrm{hr}$ fixing period (Weesner 1960). After fixation, tissues were dehydrated through graded ethanol (30 min each in 50,60,70,80,90, 95 and 100\%), cleared in $x y l e n e$ and embedded in paraffin (Weesner 1960). Sections $(7-10 \mu \mathrm{m})$ were affixed to slides with Mayer's affixative, stained with Harris Alum Hematoxylin, counter stained in Alcian B1ue and mounted in Permount (Weesner 1960).

Gill tissues for scanning electron microscopy were fixed 12 - $18 \mathrm{hr}$ in $1.25 \%$ gluteraldehyde in cacodylate buffer $\mathrm{pH} \mathrm{7.2,}$ dehydrated through graded ethanol (30 min each in 50,60, 70, 80, $90,95$ and $100 \%)$, and freeze fractured in ethanol frozen in a $1: 1$ liquid nitrogen and ethanol mixture. Fractured tissues were processed through graded ethanol/freon (5 min each in 50/50, $30 / 70,20 / 80,10 / 90,5 / 95 \%)$ to $100 \%$ freon and transferred to liquid $\mathrm{CO}_{2}$ for critical point drying. Dried tissues were epoxied to specimen stubs, coated with gold-palladium alloy, and viewed in the scanning electron microscope. 
For transmission electron microscopy, tissues were fixed in $6 \%$ gluteraldehyde in s-collidine buffer $\mathrm{pH} 7.2$, postfixed in $1 \%$ osmium tetroxide in Sorenson's phosphate buffer $\mathrm{pH} \mathrm{7.2,} \mathrm{dehydrated}$ through graded ethanol (30 min each 50,60, 70, 80, 90, 95, 100\%), cleared in propylene oxide, and embedded in EPON 812 (Glauert 1975). Thin sections were placed on 300 mesh grids, stained with uranium acetate and lead citrate, and viewed in the electron microscope. Thick sections $(1 \mu \mathrm{m})$ were placed on microscope slides, stained with a polychrome staining procedure (Griffith and Fahrenbach 1970), and viewed under a light microscope. For direct observation of feeding, a $1.5 \times 2.5 \mathrm{~cm}$ window was cut into the right valve of the oyster and a similar portion of the mantle removed to allow observation of the gill and the gill/palp interface. The window was sealed with a glass slide held to the shell with wax.

Isochrysis galbana an ovoid, golden brown alga, was grown in an enrichment culture medium (Breese and Malouf 1975) for 48 $72 \mathrm{hrs}$ at $18^{\circ} \mathrm{C}$ in a constant light system. Various concentrations and mean cell sizes of this alga were used in feeding experiments. Oysters of $7-8 \mathrm{~cm}$ in shell length were kept in filtered sea water for $24 \mathrm{hrs}$ before feeding. Experiments were conducted in 3 liter chambers, taking samples from the inhalent and exhalent regions of the feeding oyster at 20 or 30 minute intervals. Samples were counted in a Coulter counter using a $70 \mu \mathrm{m}$ aperature tube. Calibration settings used were $1 /$ current $=2,1$ amplification $=1$, and sample volume $=0.5 \mathrm{ml}$. All particle counts and volume measurements were made immediately following each feeding experiment. 


\section{RESULTS}

Crassostrea gigas is normally found resting on its left side with its four lamella gill floating in the water filled mantle cavity (Fig. 2). All lamellae appear to be symmetrical and identical to one another in structure. Each gill lamella is formed by a tissue sheet that is folded back on itself and attached to itself at regular intervals by interlamellar tissue junctions (Fig. 3). The spaces between the sheets which are bounded by the interlamellar tissue junctions are the water tubes through which water flows from the inhalent to the exhalent aperature.

The lamellae are drawn into plicae giving them a pleated appearance. Each plica is composed of 13 - 17 ordinary filaments arranged in a dorso-ventral direction (Fig. 4). The ordinary filaments are attached to each other at their bases by tissue bridges (Fig. 4 and 5). These tissue bridges help to maintain constant form in the plicae as well as forming the boundaries of the ostia, which are located at regular intervals between the ordinary filaments (Fig. 5). The ostia open into water channels which are located within each plica. These water channels are also bounded by the tissue bridges, and open into the water tubes at regular intervals (Fig. 6). A principal filament is located at the base of each plica (Fig. 4). Ciliary tracts observed on the ordinary filaments include frontal cilia, and laterofrontal cilia (Fig. 7 and 8). Frontal and lateral cilia are found on the principal filament (Fig. 4). Each lamella 


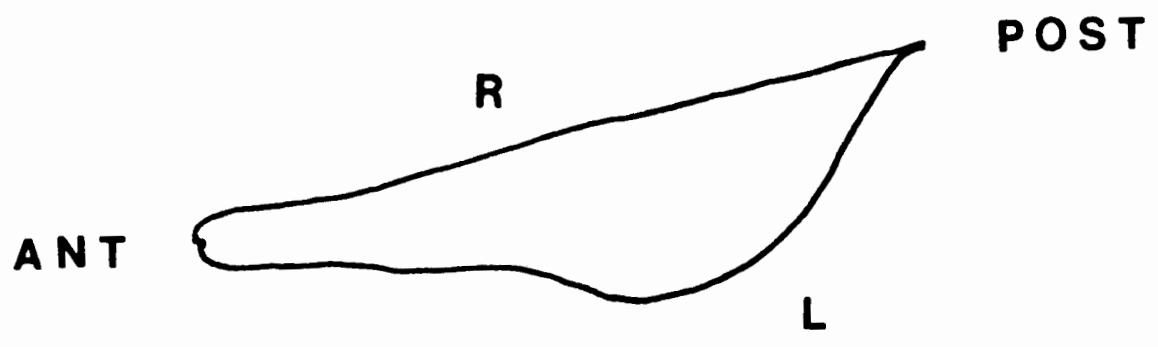

(a)

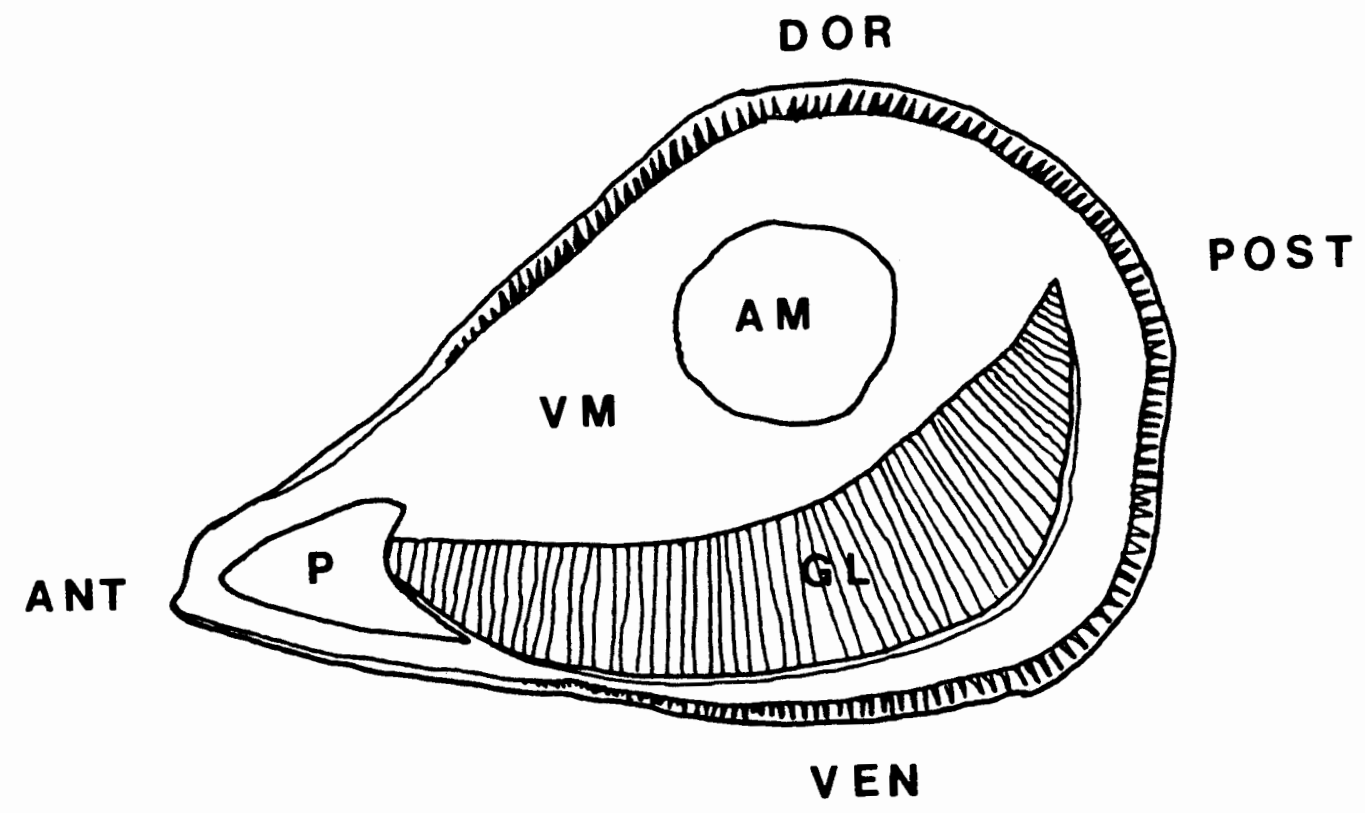

(b)

Figure 2. Simple diagramatic view of $C$. gigas: (a) representing the orientation in its natural habitat. Right side $(R)$, left side (L); (b) left valve removed displaying adductor muscle (AM), gill lamella (GL), palp (P), visceral mass (VM). 


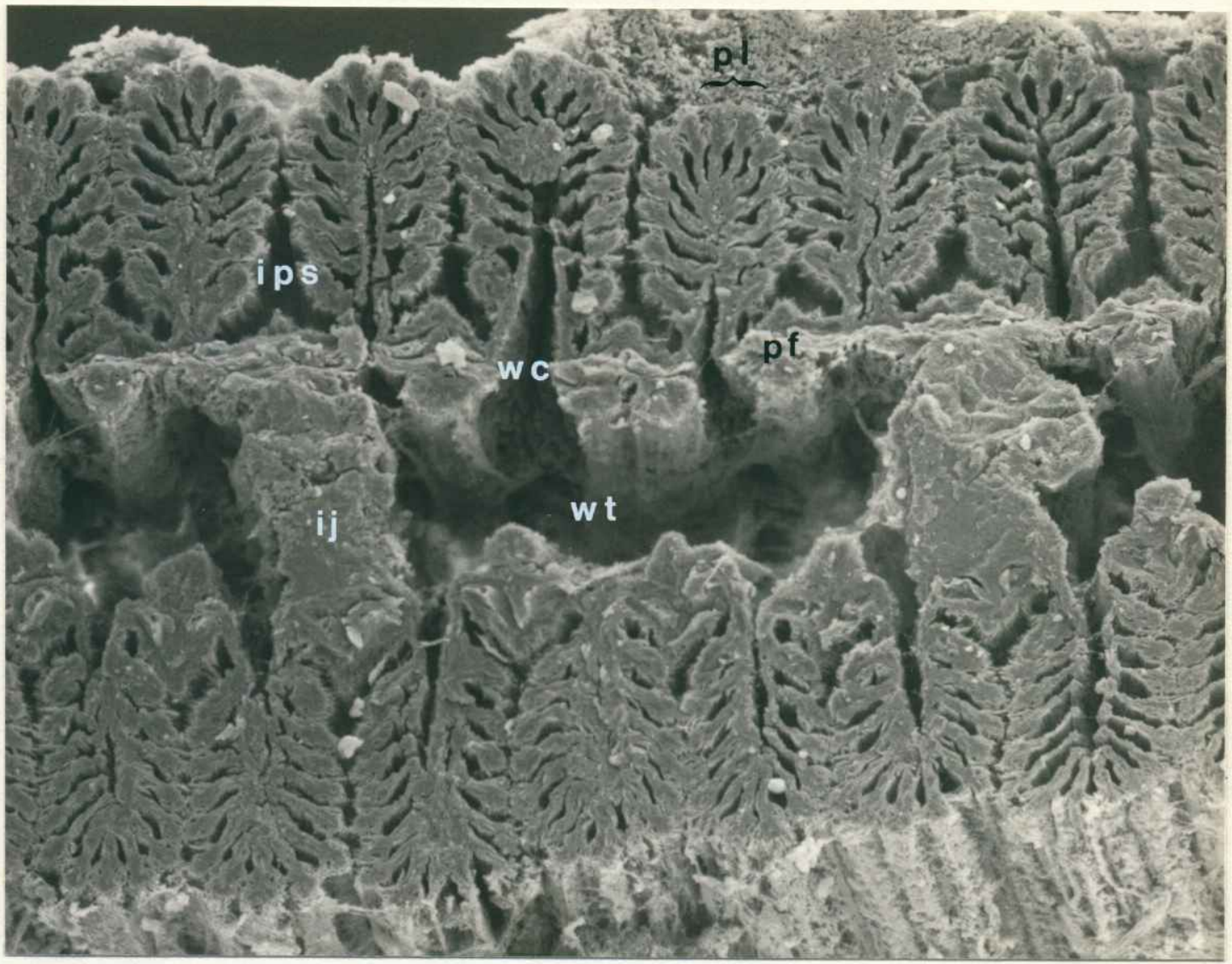

Figure 3. Scanning electron micrograph of a frontal section of gill lamella of C. gigas: interlamellar tissue junction (ij), interplical space (ips), principal filament (pf), plica (pl), water channel (wc), water tube (wt), magnification 100X. 


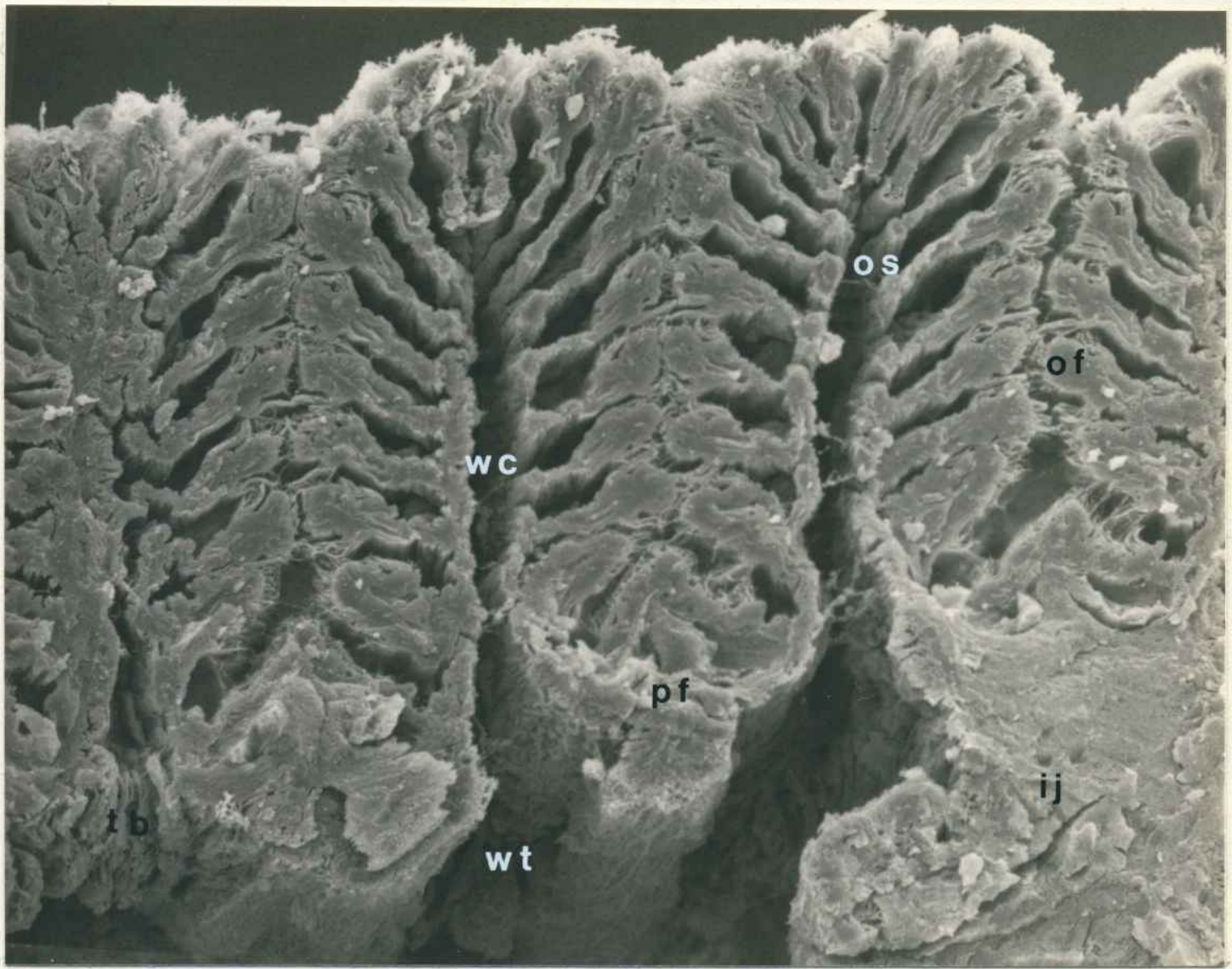

Figure 4. Scanning electron micrograph of a frontal section of gill lamella of C. gigas: interlamellar tissue junction (ij), ordinary filament (of), ostium (os), principal filament (pf), tissue bridge (tb), water channel (wc), water tube (wt), magnification $200 x$. 


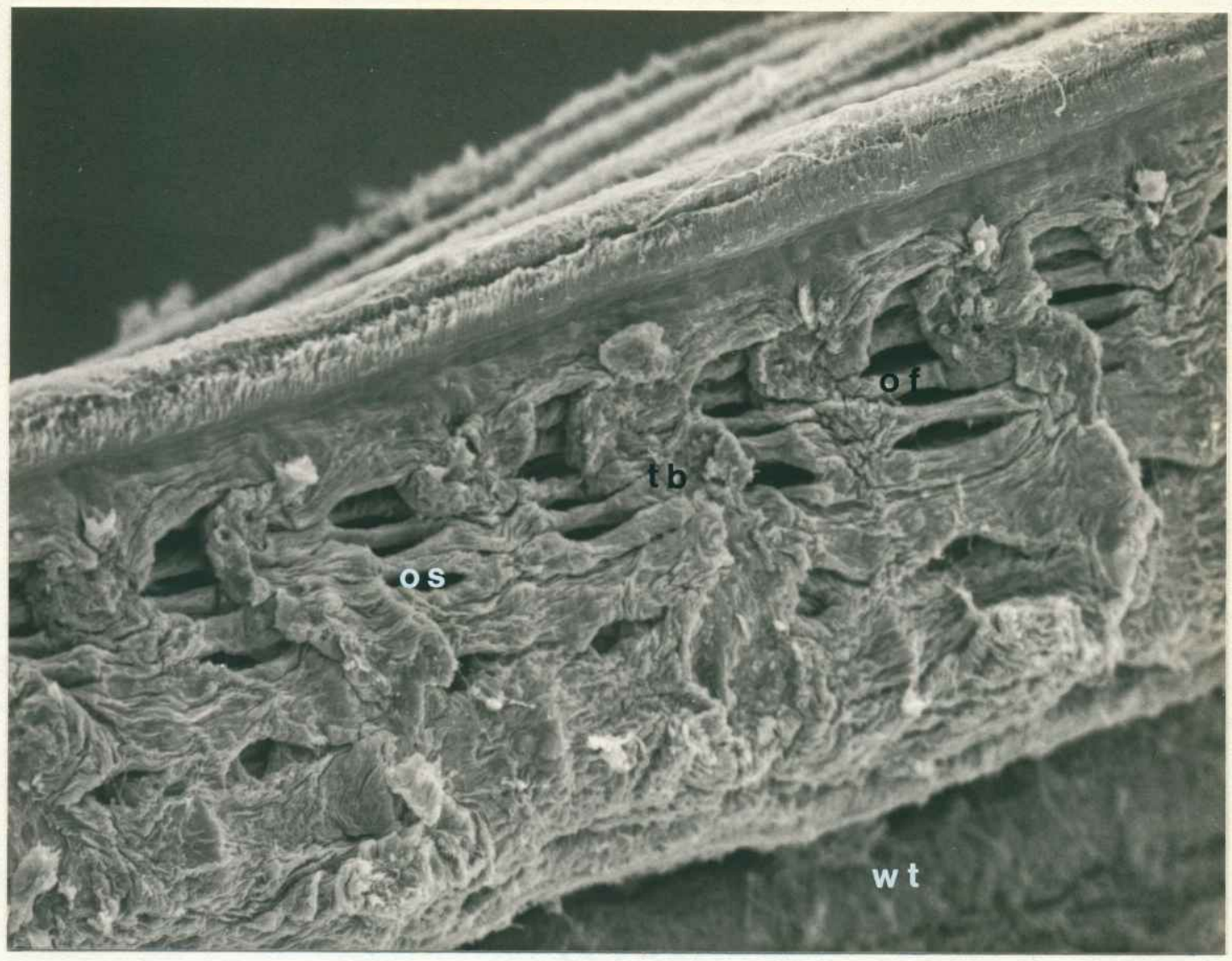

Figure 5. Scanning electron micrograph of a cross section of gill lamella of C. gigas: base of ordinary filament (of), ostium (os), tissue bridge ( $t b)$, water tube (wt), magnification $200 x$. 


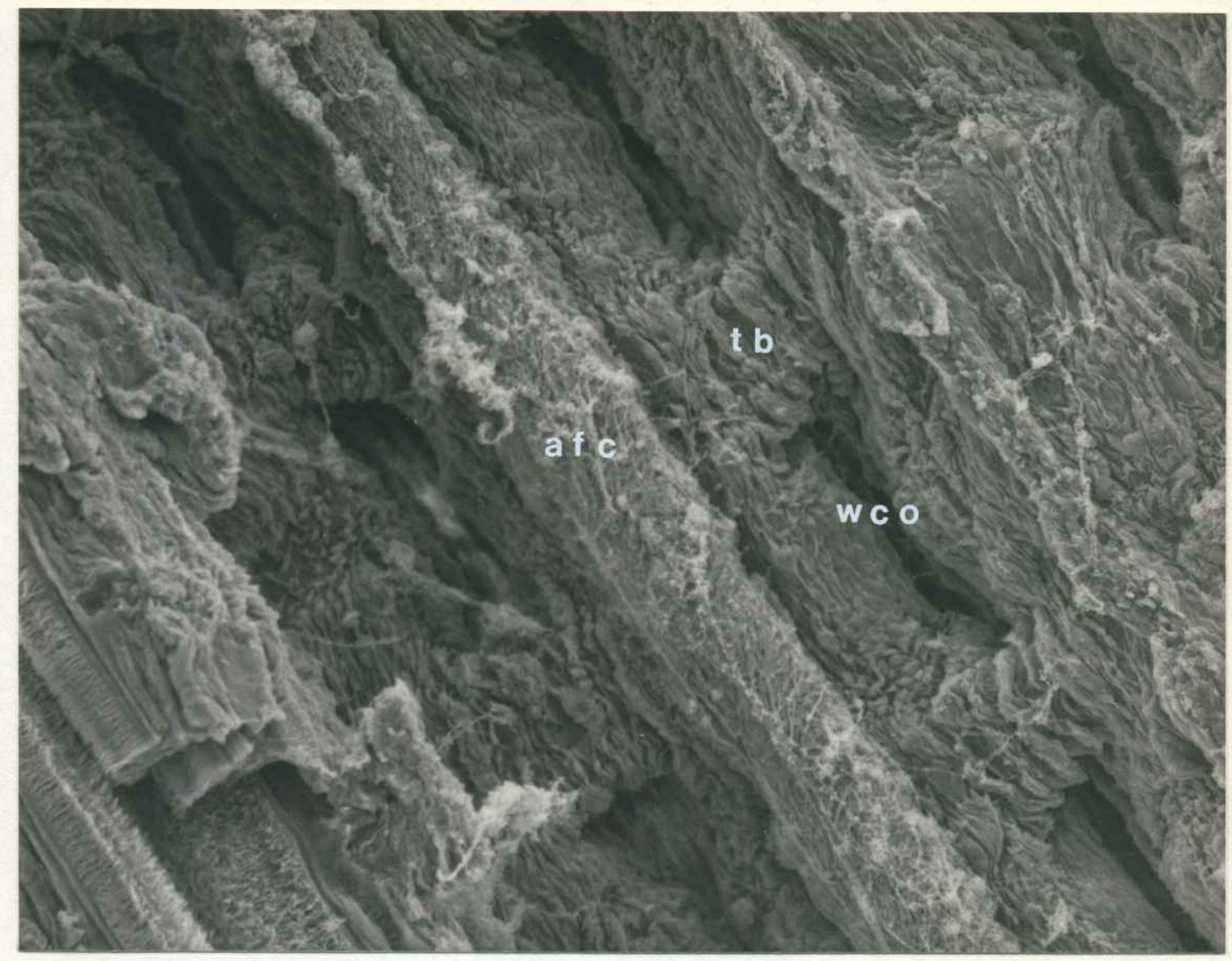

Figure 6. Scanning electron micrograph of a sagital section of gill lamella of $C_{\text {. }}$ gigas: principal filament with abfrontal cilia (afc), water channel opening into water tube (wco), tissue bridge (tb), magnification 200x. 


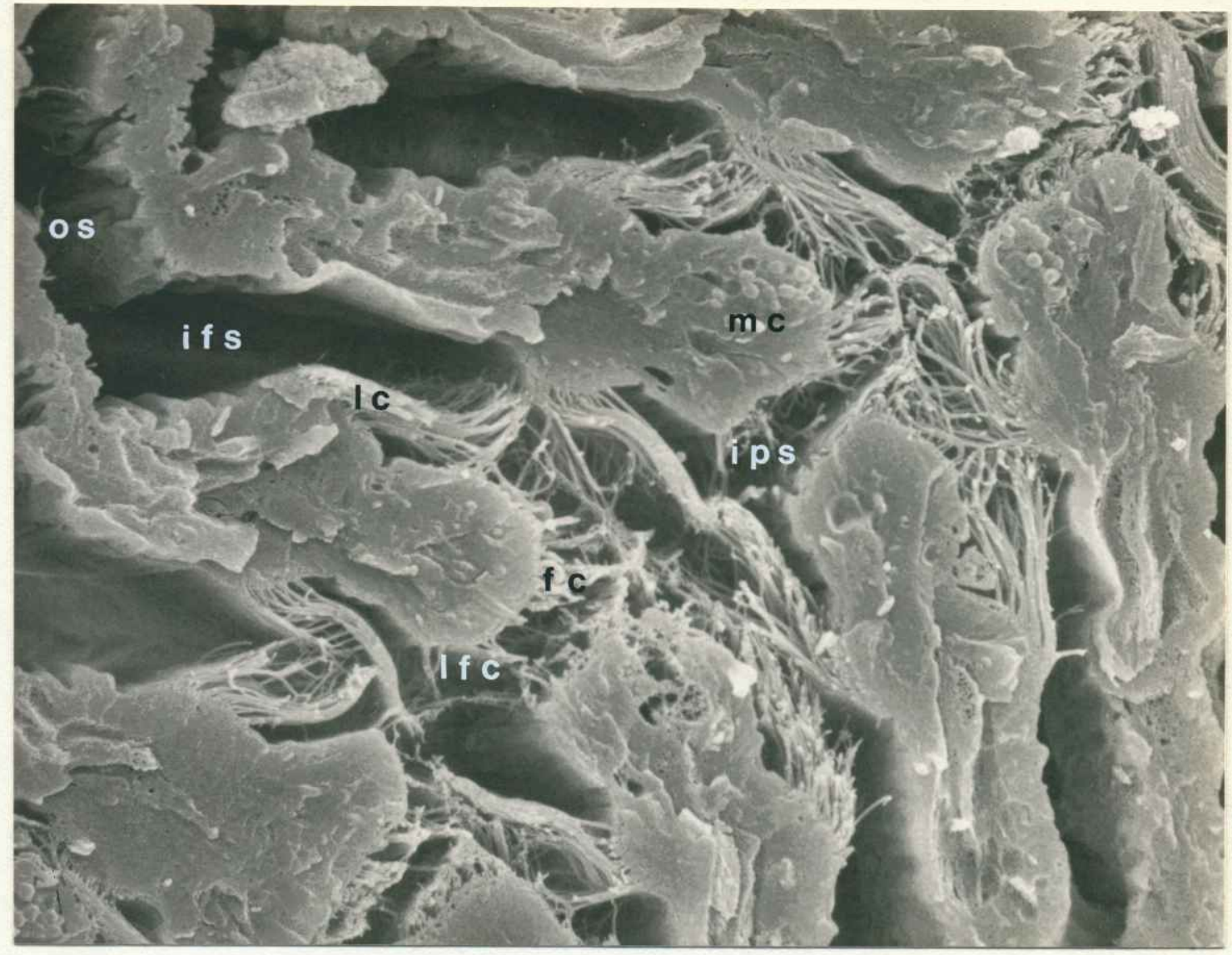

Figure 7. Scanning electron micrograph of a frontal section of gill lamella of $C_{0}$ gigas: frontal cilia (fc), interfilamentary space (ifs), interplical space (ips), lateral cilia (1c), laterofrontal cilia (1fc), mucus cell (mc), ostium (os), magnification 1000X. 


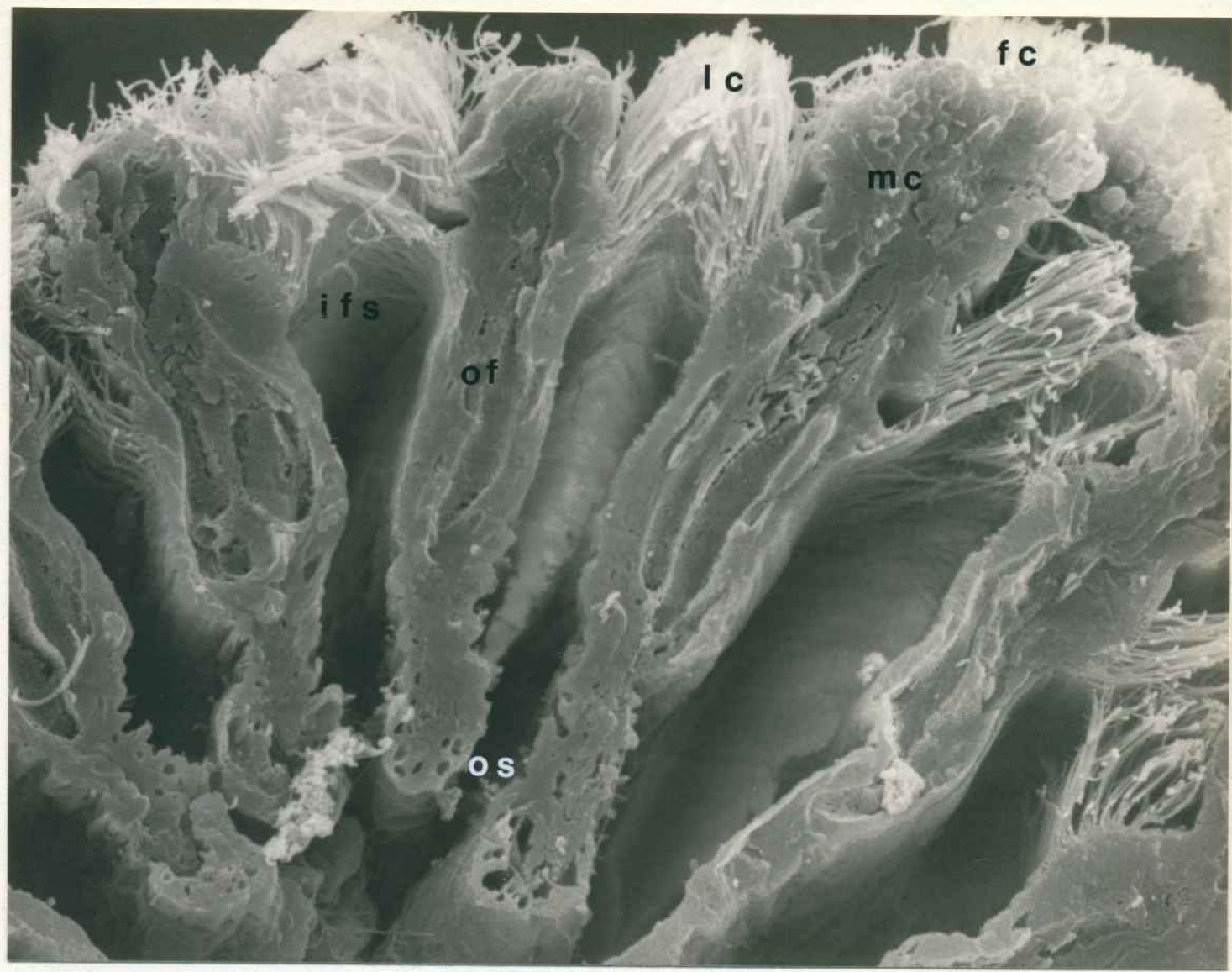

Figure 8. Scanning electron micrograph of a frontal section of gill lamella of C. gigas: frontal cilia (fc), lateral cilia (1c), interfilamentary space (ifs), mucus cell (mc), ordinary filament (of), ostium (os), magnification 1000X. 
is attached dorsally to the visceral mass. The ventral or marginal edge is folded into a furrow or groove.

Direct observation of particles on isolated gill sections shows that particles move ventrally along the frontal ciliary tracts of the ordinary filaments and dorsally along the frontal ciliary tracts of the principal filaments. Observation of intact gills through windows reveals a less simplistic view. Carmine particles presented to the gaping oysters inhalent region were quickly visible in the mantle cavity when viewing through the window with a dissecting microscope. As particles were caught up in the frontal ciliary current of the ordinary filaments, they were moved ventrally. Those particles that traversed the interplical spaces to the principal filament were caught in frontal ciliary currents that moved them dorsally. Particles moving in one direction may stop and begin moving in the opposite direction, having apparently been moved from the frontal ciliary current of an ordinary filament to the frontal ciliary current of a principal filament. This reversal of particle direction occurs only deep within the interplical spaces and not on the crest of the plicae where only ventrally beating cilia are present.

From these observations, a course of water flow through this oyster has been constructed (Fig. 9). The metachronal beating of large lateral cilia create a negative pressure in the mantle cavity. Water flows convectively through the inhalent region into the mantle cavity, between the plicae and into the interfilamentary spaces. 
Figure 9. Line diagram of frontal section of gill lamella with arrows indicating water flow: frontal cilia $(\mathrm{fc})$, lateral cilia (IC), ordinary filament (of), ostium (os), principal filament (pf), tissue bridge (tb), water tube (wt). 


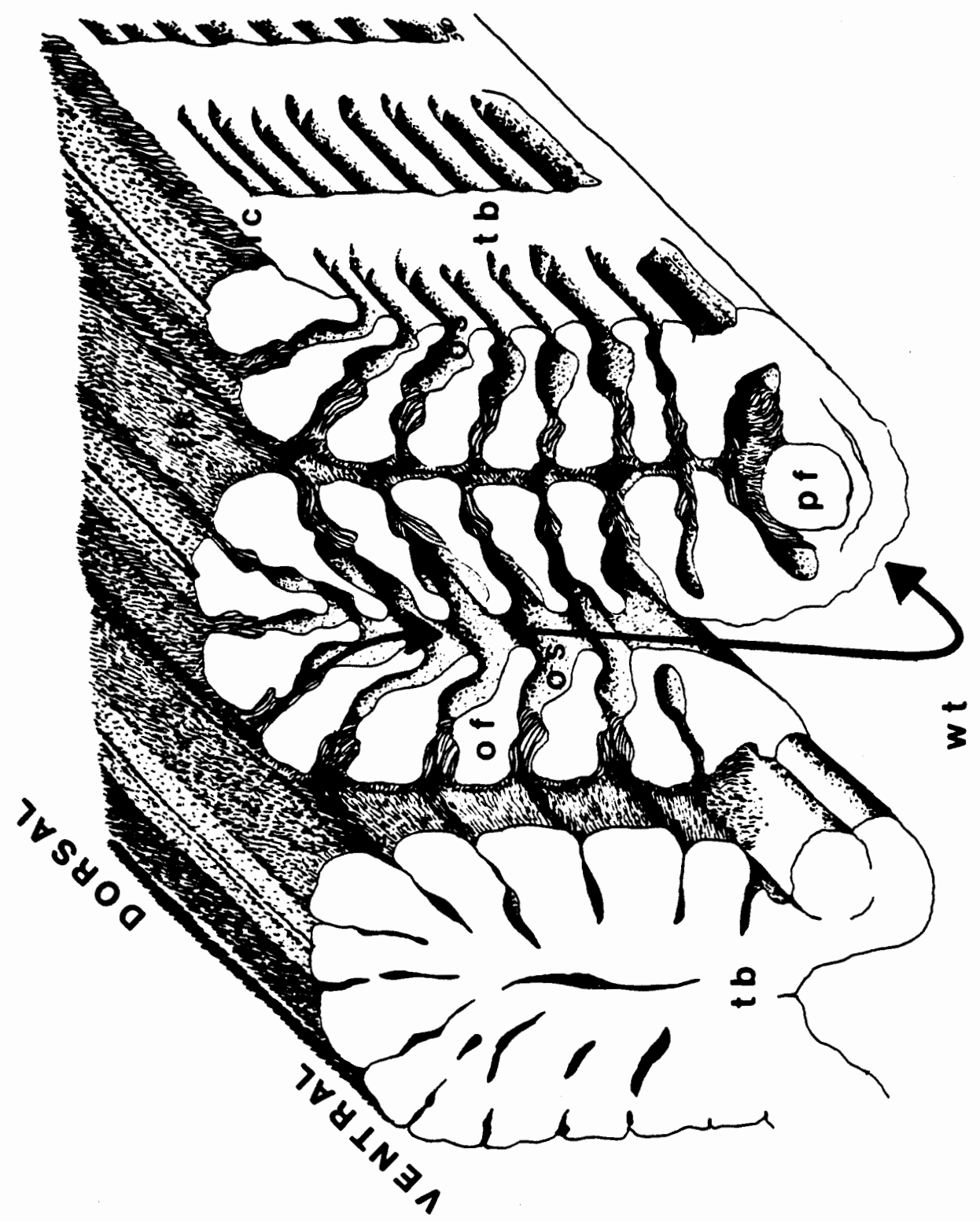


From here it moves under positive pressure through the ostia into the water channels, out into the water tubes, dorsally to the suprabranchial chamber, and out the exhalent region.

During the entire feeding observation the gill maintained its concertina movement, rythmically contracting and relaxing in such a way as to increase and decrease the interplical spaces. Particles that remain in the ventrally moving ciliary tracts are directed toward the marginal or ventral food groove where they adhere to a mucus strand which is moved anteriorly toward the palp and rejected. Particles that remain in the currents produced at the principal filament are moved dorsally to food grooves that carry them anteriorly to the palp where they are ingested. When feeding, the distance between the open valves of $C$. gigas varies along a continuum from a few to several $\mathrm{mm}$. When physically disturbed, the oyster closes its valves. The valves reopen in one to several minutes. When the valves reopen, they may open to the same aperature as before the disturbance, or they may open to an intermediate aperature and then on to their full opening. Periodic rapid closure of the valves was observed during feeding experiments. These closures often rocked the oyster when they occurred and the shell reopened in less than 30 seconds.

Eight oysters, $7-8 \mathrm{~cm}$ in shell length, were each presented with varying concentrations and sizes of algal cells. Rate of particle removal was determined by comparing intitial concentration with concentration after one hour of feeding (Fig. 10). Standard 


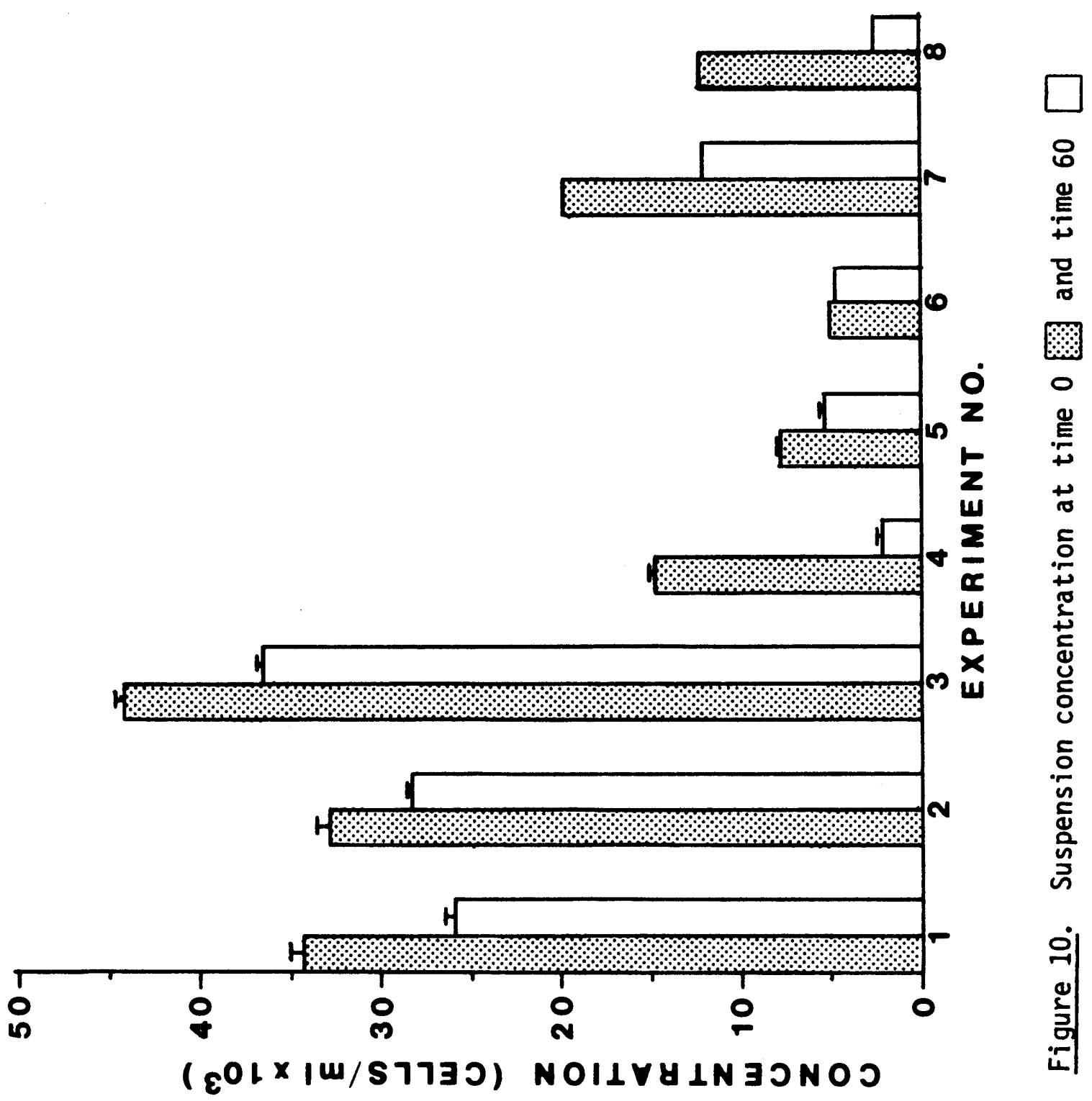


errors were determined using three consecutive particle counts and calculated $\sigma / \sqrt{n}$. Numbers for experiments 6,7 and 8 were not available for standard error calculation, but it is assumed that the precision of the Coulter counter is such that these errors would be similar to those of the other experiments. These data indicate that particle removal rate is independent of initial concentration. The particle removal rate is relatively constant over the range of concentrations tested. Particle sizes for each experiment are shown in Figure 11. This bar graph shows the average diameter particle in the initial suspension as compared to the final suspension. There is a positive correlation $(p<.05)$ between the initial diameter and the change in diameter, which indicates that the oysters are removing a greater portion of larger particles as compared to smaller particles. 


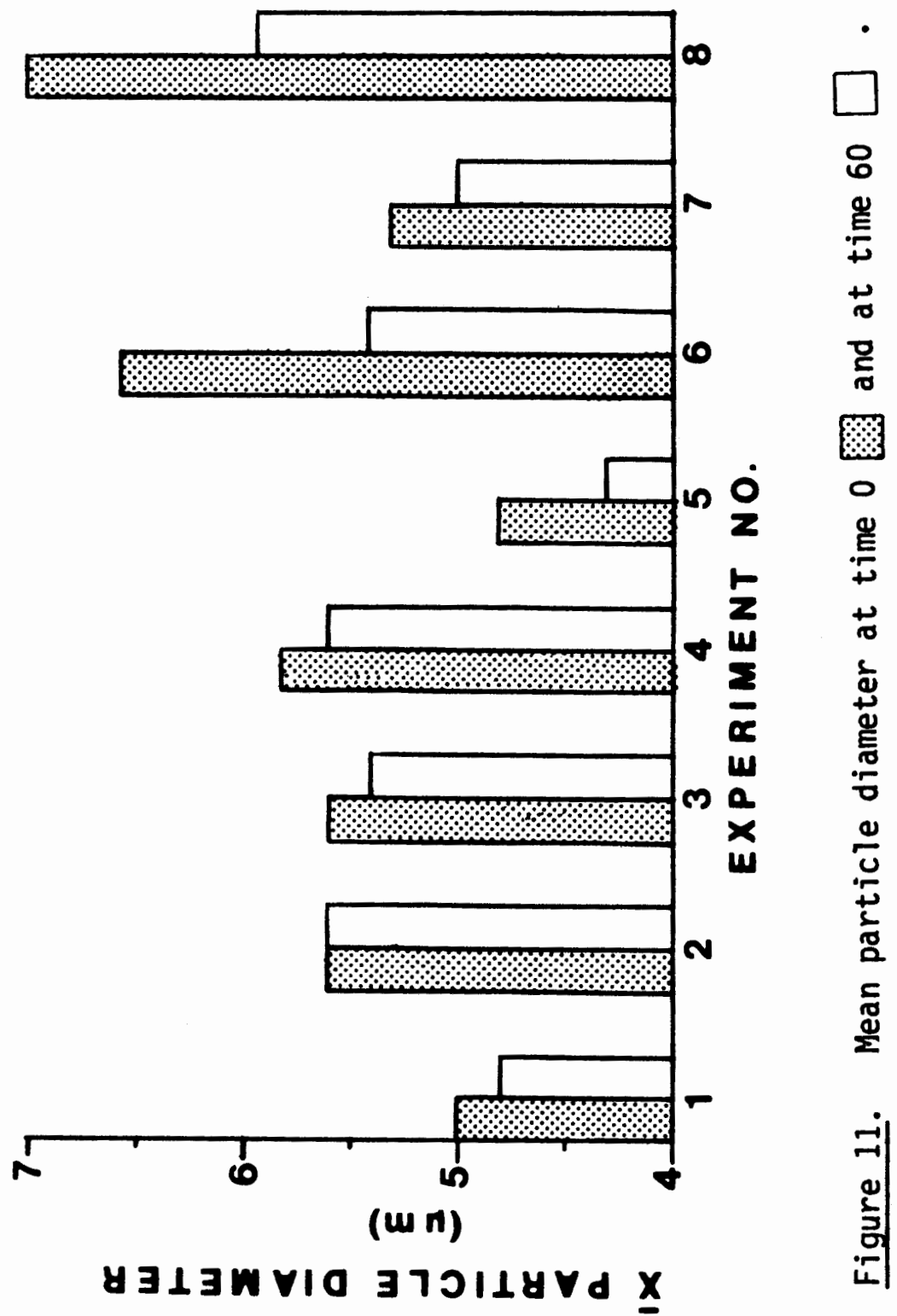




\section{DISCUSSION}

Crassostrea gigas is a soft substrate dwelling bivalve inhabiting bays and estuaries where the waters are high in sediment. Their ability to invade this habitat was greatly influenced by their ability to cleanse their gills of excessive sediments while feeding in these turbid waters. The traditional view of filter feeding in the biological world is that of straining particles tinrough a sieve. Since we look for structures that fit our concepts to explain our observations, overlapping cilia, mucus nets and porous membranes are sought to explain the removal of particles by filter feeding bivalves.

Physical stimulation of gill lamellae initiates production of large quantities of mucus. Investigation of gill function by direct observation is generally accomplished by removal of one valve, or by dissecting out a section of lamella. These methods, regardless of care taken to minimize damage, create an artificial situation in which to observe the function of the structural components of the gill. Although these methods are necessary to determine certain specific structural relationships, they are not the best way to observe natural gill function. By carefully cutting a window into the right valve and sealing it with glass (lacGinitie 1941), I was able to observe gill function in a most natural state. 
In this study, mucus was not seen to be a part of the feeding process as such, but a part of the gill cleansing and particle rejection process. Carmine particles presented to the oyster's inhalent region were observed as they traveled along the surface of the lamellae. Particles moved ventrally along the ordinary filaments toward the ventral food groove, but they were not trapped in mucus. Particles initially moving ventrally could drop into the interplical spaces and onto the principal filament where they were moved dorsally. Particles initially moving dorsally on the principal filament could move into the currents of the ordinary filaments and be carried ventrally. Note here that because of the orientation of the lamellae and the perspective of the investigator, it may be interpreted that gravity is the driving force for the particles settling into the grooves on the gill. It must be understood that the "underside" or left side of the lamella is also subject to similar forces and that all particles would fall away from it. This is surely not the case. Water drawn into the lamellae creates currents that pull particles down (or up) into the interplical spaces and into the frontal ciliary currents of the principal and ordinary filaments.

Individual particles often stopped moving for short periods of time and then started again. I interpret this interrupted movement as individual particles being caught in currents between ordinary filaments. The interaction among the ciliary currents is 
the driving force in determining the ultimate fate of a given particle.

The only mucus that I observed during these feeding observations was a continuous strand that was contained within the ventral food groove. This mucus strand moved continuously anteriorly, and all particles reaching the ventral margin were carried along with it to the palp where it was rejected to the mantle for expulsion. Particles that were directed to the dorsal food grooves were also moved anteriorly, but not in a mucus strand. These particles were passed into the palp and presumably ingested. Based on these observations, mucus is primarily a protective substance, produced under abnormal or stressful situations to trap and expel excessive or noxious particles.

Bernard (1974) showed that mucus from the marginal food groove is not ingested by $C$. gigas. His conclusion is based on a comparison between the mucus/particle ratio in the marginal food groove and the mucus/particle ratio at the mouth, the latter being less. Based on this observation, he states that the function of the palps is to reduce the amount of mucus and therefore increase the particle concentration. Using Bernard's data and my observations, a different conclusion would be that particles caught in mucus are rejected and particles not in mucus are ingested.

A leading theory in this field is one of straining particles out by use of a sieve filter. This theory is supported by structural evidence in Mytilus edulis (Owen 1974). The laterofrontal cirri 
form a mesh network of the proper dimension to explain minimum particle size removed. These data do not explain how particles larger than the mesh size get through. It is also quite unclear how these laterofrontal cirri transfer the particles, against the currents produced by the lateral cilia, to the frontal cilia. This would be like pushing tadpoles up a waterfall with the back of your hand.

Particle separation by gravitational force (Bernard 1974) is presented as a means of selecting organic (light) particles from inorganic (heavy) particles. The use of the mantle cavity as a settling chamber is unlikely in view of the rate of water flow through the anima1. It is instructive to note here that small particles attain maximum velocity in water nearly instantaneously. They also resist settling due to the relative viscosity of water with respect to their diameter. Considering the orientation of C. gigas in nature, it seems to me that the particles are pulled into the mantle cavity in such a way as to distribute them for maximal impingement on the gill surface. The left valve is cupped, so when water enters the inhalent region, it follows the contour of the valve and the particles are thrown out into the mantle cavity where the gill lamellae are located. I have seen the gills of a freshly shucked oyster which were black with sediment, presumably stirred up during the harvesting operation. I have never seen large quantities of sediment accumulated on the mantle. Controlling the rate of water flow through bivalves by 
opening and closing the ostia is said to influence particle selection (Nelson 1960, Bernard 1974, Foster-Smith 1975). The ostia in C. gigas are formed from structural elements of the plicae (Fig. 5) and are not individual membrane pores as they are often depicted. Because of this, in order to close an ostium the gill lamella would have to contract in both length and width. During normal feeding the ostia remain fully open. In fact, my observations indicate that the ostia stay open all the time. When the lamella is stimulated, the plicae immediately surrounding the area of stimulation move closer together, closing the interplical spaces in the area of stimulation. This does not affect the ostial openings. If another area of the lamella is stimulated near the first, the plicae around the area of the first stimulation move apart, reopening the interplical spaces. This movement in no way affects the ostia.

As long as the valves are open allowing water to flow into the mantle cavity, filtering of particles takes place. Since the lamellae cannot shorten to any appreciable degree, most interplical spaces are always open and allow particles through to the principal filament. These are the particles that are ingested. Particles that are caught in the frontal ciliary currents of the ordinary filaments are carried to the ventral food grooves for rejection. In this way, Crassostria gigas is able to feed in waters that contain large amounts of sediment. 


\section{CONCLUSIONS}

The plicate gill of Crassostrea gigas forms an effective filter which removes particles from the water and separates them from one another either for ingestion or rejection. Those particles that reach the principal filaments are moved dorsally to food grooves that direct them toward the mouth for ingestion. Particles caught in the currents produced by the frontal cilia of the ordinary filaments move ventrally to food grooves for rejection. There is no direct selectivity of particles based on nutritive value. Particles are selected by size, the larger being more likely to be captured by the gill than the smaller. Mucus is produced by the gill in response to excessive stimulation by large or concentrated masses of particles and forms a mechanism by which to rid the gill of excess or noxious substances. 


\section{LITERATURE CITED}

Atkins, D. 1936. On the Ciliary Mechanisms and Interrelationships of Lame11ibranchs Part I. Some New Observations on Sorting Mechanisms in Certain Lamellibranchs. Q.J. Microsc. Sci. $79: 128-308$.

Barnes, Robert D. 1976. Invertebrate Zoology, 3rd ed. W.B. Saunders Co. 870 pp.

Bernard, F.R. 1974. Particle sorting and labial palp function in the Pacific oyster Crassostrea gigas (Thunberg 1795), Biol. Bul1. 146:1-10.

Breese, W.P. and R.E. Malouf. 1975. Hatchery Manual for the Pacific Oyster. Oregon State University Sea Grant College Program, Publication no. ORESU-H-75-002.

Buley, H.M. 1936. Consumption of diatoms and dinoflagellates by the mussel. Butl. Scripps Instn. Oceanogr. Tech. Ser. $4: 19-27$.

Dral, A.D.G. 1967. The movements of the latero-frontal cilia and the mechanism of particle retention in the mussel (Mytilus edulis L.). Netherlands J. Sea. Res. 3:391-422.

Foster-Smith, R.L. 1975. The effect of concentration of suspension on the filtration rates and pseudofecal production for Mytilus edulis (L.), Cerastoderma edule (L.) and Venempis pulzastra (Montagu). J. Exp. Mar. Biol. Ecol. 12:1-22.

Glauert, Audrey M. 1975. Fixation, Dehydration and Embedding of Biological Specimens. American Elsevier Publishing Co. Inc. New York, $207 \mathrm{pp}$.

Griffith, A.J. and W.H. Fahrenbach. 1970. Polychrome stain for plastic sections. Modified from Mackay and Mead, 28th EMSA Meetings, 1970.

Jørgensen, C.B. and E.D. Goldberg. 1953. Particle filtration in some Ascidians and Lamellibranchs. Biol. Bull. 105: 477-489.

Jprgensen, C.B. 1966. Biology of Suspension Feeding. Oxford: Pergammon Press. $357 \mathrm{pp}$. 
Jørgensen, C.B. 1975. Comparative Physiology of Suspension Feeding. Ann. Rev. Phys. 37:57-79.

Jorgensen, C.B. 1981. A hydromechanical principle for particle retention in Mytizus edulis and other ciliary suspension feeders. Mar. Biol. 61:277-282.

Loosanoff, V.L. 1949. On the food selectivity of oysters. Science $110: 122$.

MacGinitie, G.E. 1941. On the method of feeding four pelycepods. Biol. Bul1. 80:18-25.

Hoore, J.H. 1971. The structure of the laterofrontal cirri on the gills of certain lamellibranch molluscs and their role in suspension feeding. Mar. Biol. 11:23-27.

Nelson, T.C. 1960. The feeding mechanisms of the oyster II. On the gills and palps of Ostrea edulis, Crassostrea virginica, and Crassostrea angulata. J. Morph. 107:163-283.

Owen, G. 1974. Studies of the gill of Mytizus eduzis: the eulaterofrontal cirri. Proc. R. Soc. Lond. B. 187:83-91.

Owen, G. and J.H. McCrae. 1976. Further studies on the laterofrontal tracts of bivalves. Proc. R. Soc. Lond. B. Biol. Sci. 194(1117):527-544.

Rubenstein, Daniel I. and M.A.R. Koehl. 1977. The mechanisms of filter feeding: some theoretical considerations. Am. Nat. 111(981):981-994.

Smith, Ralph I. and James T. Carlton, eds. 1977. Lights Manual: Intertidal invertebrates of the Central California coast. 4th ed. University of California Press. 716 pp.

Tammes, P.M.L. and A.D.f. Dral. 1955. Observations on the straining of suspensions by mussels. Arch. Neer1. Z0o1. 11:87-112.

Weesner, Frances M. 1960. General Zoological Microtechniques. The Williams and Wilkins Co. Baltimore, Md.

Winter, J.E. 1978. A review of the knowledge of suspension feeding in lamellibranchiate bivalves, with special reference to artificial aqualculture systems. Aquaculture. 13:1-33. 